\title{
Effect of Schinus Terebinthifolius Extracted Oil, 8- Hydroxyquinoline Sulphate and Citric Acid on The Longevity and Quality of Calla Lily Cut Flowers
}

\author{
Magd el Din F. Rida ${ }^{1}$, Rehab A. Soffar ${ }^{1}$, Mohamed Z.M. Salem ${ }^{2}$ \\ 1 Ornamental Plants Research Department, Horticulture Research Institute, ARC, \\ Alexandria, Egypt. \\ 2 Forestry and Wood Technology Department, Faculty of Agriculture (EL-Shatby), \\ Alexandria University, Alexandria, Egypt
}

\begin{abstract}
This investigation was carried out at Antoniades Research Branch, Horticulture Research Institute, Ministry of Agriculture, Alexandria, Egypt during 2014 and 2015 seasons. The study was a trial to investigate the effects of using Schinus terebinthifolius extracted (essential oil) at $(0.3,0.6$ and $0.9 \mathrm{ml}$ oil/L) as an environmentally safer treatment, Citric acid at $(0.1,0.2$ and $0.3 \mathrm{~g} / \mathrm{L})$ and 8-hydroxyquinoline sulphate [8-HQS] at $(100,150$ and 200 $\mathrm{mg} / \mathrm{L}$ ) on the cut flowers of Zantedeschia aethiopica $L$. to define the best concentrations treatments to enhance the postharvest quality and the vase life. All treatments used caused a significant increase in the calla-lily vase life compared to control. The $S$. terebinthifolius essential oil treatments gave the lowest loss of flower fresh weight percentage (LFFW) in both seasons. The highest significant amount of water absorbed by calla- lily flowers were obtained from $S$. terebinthifolius essential oil treatment at $0.9 \mathrm{ml} / \mathrm{L}$ in both seasons which resulted in more freshness upon the cut flowers. The reducing sugar content obtained from all treatments was better than control. Both the treatment of $8-\mathrm{HQS}$ at $200 \mathrm{mg} / \mathrm{L}$ and of $0.9 \mathrm{ml} / \mathrm{L}$ S. terebinthifolius essential oil prolonged the vase life of cut flowers. However the cut flowers resulted from the alternative environmentally safer treatment $0.9 \mathrm{ml} / L$ of $S$. terebinthifolius essential oil at the end of the experiment, was more fresh compared with those of $200 \mathrm{mg} / \mathrm{L}$ of $8-\mathrm{HQS}$ treatment.

Key words: vase life - Zantedeschia aethiopica - 8-hydroxyquinoline sulphate [8-HQS] Citric acid -Schinus terebinthifolius extracted oil
\end{abstract}

\section{INTRODUCTION}

Vase life of cut flowers is an important factor in consumer preference. Short vase life is one of the most limiting factors related to cut flowers (Kader, 2003; Ahsan et al., 2012). Under normal conditions, cut flowers could last only for a few days maintaining their beauty and attractiveness. However, most of the people like to enjoy cut flowers in their natural beauty and appearances for a longer period of time having the socioeconomic value of flowers intact (Tsegaw et al., 2011; Zamani et al., 2011). Hence there is a dire need to explore possibilities of extending vase life by using different biocides (Chapman and Austinbrown, 2007).

The effectiveness of hydroxyquinoline (HQ) as an apparent biocide in cut flower handling solutions has been known for decades (Van Doorn, 1997). Sulphate (HQS) and citrate (HQC) are the most commonly used $\mathrm{HQ}$ compounds in flower handling (Loubaud and Van Doorn, 2004; Van Doorn, 1997).Citric acid (CA) is a widespread organic acid in the plant kingdom and makes a weak acid in water. Citric acid is commercially advised for a number of cut flowers like chrysanthemum (Dole et al., 1999). Also, CA reduces the risk of vascular blockage in cut flowers through its anti- embolism trait (Bhattacharjee et al., 1993). 
Recently, natural compounds such as plant essential oils are used as a new idea for controlling bacterial and fungal contamination and reducing postharvest losses of horticultural crops such as fruits, vegetables and flowers. Researches and commercial applications have revealed that natural compounds can be a suitable replacement for common chemical compounds (Solgi et al., 2009). Hegazi and El-Kot (2009) showed that the essential oils of clove hindi, cinnamon, ginger, marjoram and fennel are used for gladiolus to reduce microbes accumulation in containers and increase the vase life.

Schinus terebinthifolius plant is known as Brazilian pepper, Aroeira, Florida holly, Rose pepper, or Christmas berry belongs to the Anacardiaceae family (Manrique et al., 2008). The plant has a very long history of use and appears in ancient religious artifacts and on idols among some of the ancient Chilean Amerindians. In South and Central America, Brazilian pepper tree is reported to have astringent, antibacterial, antiviral and wound healing properties. (Molina-Salinas et al., 2006).

Zantedeschia aethiopica (known as calla lily and arum lily) is a species in the family Araceae, native to Southern Africa in Lesotho, South Africa, and Swaziland. It is a rhizomatous herbaceous perennial plant (Courtier and Clarke ,1997) It is produced and marketed as a cut flower and a flowering potted plant for its attractive spathes, commonly referred to as flowers ( Brian and Richard, 1991).

The aim of this study was to investigate the effects of Schinus terebinthifolius extracted essential oil, Citric acid and 8-hydroxyquinoline sulphate (8-HQS) on the vase life and quality of cut Zantedeschia aethiopica and find the best concentrations treatments to enhance the vase life of cut calla lily.

\section{MATERIALS AND METHODS}

The present study was carried-out at Antoniades Research Branch, Horticulture Research Institute, A.R.C. Alexandria, Egypt during the two successive seasons of 2014 and 2015.

\section{A-Source of the cut flowers:}

Cut flowers were obtained from a well-known commercial nursery in Alexandria.

\section{B-Cut flowers preparations:}

The harvest point of cut flowers was determined when the inflorescences were completely open, before the spathe tip curled down and without pollen on the spadix (Nowak \& Runicki , 1990). On the $7^{\text {th }}$ of May 2014 and 2015 (in the first and second seasons, respectively), cut flowers were transported to the laboratory under dry conditions, they were recut before treatments to the length of $75 \mathrm{~cm}$ and put in a conditioning treatment (5\% sucrose solution in distilled water for 12 hours). 


\section{C-Preparation of essential oil from Schinus terebinthifolius:}

Fruits of Schinus terebinthifolius were cut into small pieces (100 grams) and hydro-distillated for $3 \mathrm{~h}$, in a Clevenger apparatus 48 (Salem et al., 2013). The oil was dried over anhydrous $\mathrm{Na}_{2} \mathrm{SO}_{4}$, and measured with respect to the mass of fresh weight of fruits $(6.65 \mathrm{~mL} / 100$ grams fresh weight). The oil was kept dry in sealed Eppendorf tubes and stored at $4{ }^{\circ} \mathrm{C}$.

\section{D-Chemicals used in the experiment:}

1-8-hydroxyquinoline sulphate (8-HQS) at concentrations of (100-150 and 200 $\mathrm{mg} / \mathrm{L}$ ) in distilled water.

2- Citric acid (CA) at concentrations of $(0.1,0.2$ and $0.3 \mathrm{~g} / \mathrm{L})$ in distilled water 3Schinus terebinthifolius essential oil at concentrations of $(0.3,0.6$ and $0.9 \mathrm{ml}$ of extracted oil /L) .

\section{E-Cut flower treatments:}

On the $8^{\text {th }}$ of May 2014 and 2015 (in the first and second seasons, respectively) conditioned flowers were recut to $70 \mathrm{~cm}$ and put in glass jars containing the three previous chemicals and distilled water (control) and the flowers were remained in the lab at the average temperature of $\left(23.5^{\circ}-25^{\circ}\right)$ and average humidity ( $55 \%-57 \%$ ).

\section{F-Experimental layout and statistical analysis:}

The experimental layout was a randomized complete block design (RCBD). It consists of ten treatments with three replicates each treatment contains three cut flowers. The means of the individual factors and their interactions were compared by L.S.D test at $5 \%$ level of probability. The data were statistically analyzed according to the method described by Snedecor and Cochran (1989).

\section{G-Data were recorded as the following: \\ 1-The postharvest characters \\ a- Vase life (days)}

It was determined as the number of days from starting the experiment to the fading stage. The fading stage was set at the point when the cut flower turned green or when the tops of the spathes had dried. (Beata and Anna, 2011).

b- Loss of flower fresh weight percentage (L.F.F.W ): $., 2013)$

It was determined at the fading stage as the flowing formula (Tarek et al

$$
\text { L.F.F.W. }(\%)=\frac{\text { Initial fresh weight }- \text { Final fresh weight }}{\text { Initial fresh weight }} \times 100
$$

\section{c- Final water uptake (g):}

It was calculated at the end of the experiment as the following formula

Water uptake $(\mathbf{g})=$ The amount of solution at the beginning of the experiment - the amount of the solution remaining at the end of the experiment 


\section{d- Flower fresh weight / flower dry weight ratio ( FWR) :}

At the fading stage the flowers were oven dried at $75^{\circ} \mathrm{C}$ for 48 hours to get the flower dry weight ( F.D.W.) Then the fresh weight was divided by the dry weight as below (Mahmoud ,2013).

$$
F W R=\frac{\text { Fresh weight per flower }(\mathrm{g})}{\text { Dry weight per flower }(\mathrm{g})}
$$

\section{e- Relative fresh weight (RFW)}

Fresh weight of the flowers was determined just before the immersion of the flowers into the solutions and collected every two days until the vase life of the flowers was terminated. The fresh weight of each flower was expressed relative to the initial weight to represent the water status of the flower (He et al., 2006)

$$
\text { Relative fresh weight }(\mathrm{RFW})=\frac{W t}{w 0} \times 100
$$

Where $W t$ is the weight of stem (g) at $11^{\text {th }}$ May, $13^{\text {th }}$ May and $15^{\text {th }}$ May and WO is the initial fresh weight of the same stem $(\mathrm{g})$

\section{f- Vase Solution Uptake Rate:}

The VSU rate was measured according to the formula below (Damunupola, 2009)

$$
\text { VSU rate }=\frac{(\mathrm{St}-1)-\mathrm{St}}{\mathrm{IFW} \text { of stem }} \times \mathbf{1 0 0}
$$

Where (St ) is weight of vase solution (g) at $11^{\text {th }}$ May , $13^{\text {th }}$ May and $15^{\text {th }}$ May ,(St-1) is weight of the vase solution (g) on the previous day and (IFW) is the initial fresh weight $(\mathrm{g})$.

\section{2- Chemical analysis}

Reducing sugar content (\%)

Reducing sugar content was determined in dried spathes according to the method described by Malik and Singh (1980) .

\section{RESULTS}

\section{1-The postharvest characters}

\section{a-Vase life (days)}

Data presented in Table (1) showed that the 8-HQS treatments, $S$. terebinthifolius essential oil at $(0.3 \mathrm{ml} / \mathrm{L}$ and $0.9 \mathrm{ml} / \mathrm{L})$ and Citric acid at $0.2 \mathrm{~g} / \mathrm{L}$ gave the highest vase life in the first season .However the treatments of 8- HQS at $200 \mathrm{mg} / \mathrm{L}$, schinus extracted oil at $0.9 \mathrm{~m} / \mathrm{L}$ and Citric acid at $0.3 \mathrm{~g} / \mathrm{L}$ gave the highest significant vase life in the second season. On the other hand, the lowest vase life was noted in the control treatment ( 7 and 8 days ) in the first and second season, respectively .

\section{b- Loss of flower fresh weight percentage LFFW ( \%)}

Table (1) cleared that the highest LFFW was obtained from control treatment (35.97 and 31.51\%) in the first and second season, respectively. On the other side, all $S$. terebinthifolius essential oil treatments gave the lowest LFFW in both seasons. 
Table (1). Average of vase life (days) and loss of flower fresh weight (LFFW) (\%) of calla -lily cut flowers as affected by $8 \mathrm{HQS}$, Schinus terebinthifolius essential oil and citric acid in the seasons of 2014 and 2015.

\begin{tabular}{|c|c|c|c|c|}
\hline \multirow{2}{*}{ Treatment } & \multicolumn{2}{|c|}{ Vase life (days ) } & \multicolumn{2}{|c|}{ Loss of flower fresh weight LFFW (\%) } \\
\hline & 2014 & 2015 & 2014 & 2015 \\
\hline Control (distilled water) & $7.00^{\mathrm{C}}$ & $8.00^{\mathrm{d}}$ & $35.97^{\mathrm{a}}$ & $31.51^{\mathrm{a}}$ \\
\hline $8 H Q S 100 \mathrm{mg} / \mathrm{L}$ & $10.33^{a}$ & $10.00^{\mathrm{b}}$ & $27.43^{C}$ & $29.33^{\mathrm{abc}}$ \\
\hline $8 \mathrm{HQS} 150 \mathrm{mg} / \mathrm{L}$ & $10.00^{a}$ & $9.67^{\mathrm{bc}}$ & $29.35^{c}$ & $28.15^{\mathrm{cd}}$ \\
\hline $8 \mathrm{HQS} 200 \mathrm{mg} / \mathrm{L}$ & $11.00^{\mathrm{a}}$ & $11.33^{\mathrm{a}}$ & $28.03^{c}$ & $28.84^{\mathrm{bcd}}$ \\
\hline Essential oil $0.3 \mathrm{~m} / \mathrm{L}$ & $10.00^{\mathrm{a}}$ & $9.67^{\mathrm{bc}}$ & $23.46^{\text {et }}$ & $23.76^{\dagger}$ \\
\hline Essential oil $0.6 \mathrm{~m} / \mathrm{L}$ & $9.67^{\mathrm{b}}$ & $10.00^{\mathrm{b}}$ & $22.47^{\text {et }}$ & $24.83^{\mathrm{et}}$ \\
\hline Essential oil $0.9 \mathrm{~m} / \mathrm{L}$ & $10.00^{\mathrm{a}}$ & $10.33^{a}$ & $21.08^{\dagger}$ & $23.69^{\dagger}$ \\
\hline Citric acid $0.1 \mathrm{~g} . / \mathrm{L}$ & $8.33^{\mathrm{bc}}$ & $8.67^{\mathrm{cd}}$ & $32.61^{\mathrm{b}}$ & $30.91^{\mathrm{ab}}$ \\
\hline Citric acid 0.2 g./L & $10.00^{\mathrm{a}}$ & $8.33^{c d}$ & $26.91^{\mathrm{cd}}$ & $26.40^{\text {de }}$ \\
\hline Citric acid $0.3 \mathrm{~g} . / \mathrm{L}$ & $9.33^{\mathrm{b}}$ & $10.33^{a}$ & $24.44^{\mathrm{de}}$ & $25.01^{\text {ef }}$ \\
\hline L.S.D.at 0.05 & 1.55 & 1.16 & 2.76 & 2.57 \\
\hline
\end{tabular}

Means of treatments in the column have the same letters, are not significantly different at $5 \%$ level .

\section{c- Final water uptake $(g)$}

Table (2) showed that the highest significant amount of water absorbed by calla- lily flowers were recorded from the treatments of $S$. terebinthifolius essential oil at $0.9 \mathrm{~m} / \mathrm{L}(24.79$ and $23.83 \mathrm{~g})$ in the first and second seasons respectively. On the other hand, the control treatment gave the lowest significant water uptake (14.28 and 16.65g) in the first and second season, respectively.

\section{d-Fresh weight /dry weight ratio (FWR)}

Results in Table (2) cleared that the highest FWR (33.17) was obtained from Citric acid treatment at $(0.3 \mathrm{~g} / \mathrm{L})$ in the first season and both Citric acid at ( $0.3 \mathrm{~g} / \mathrm{L})$ and $S$. terebinthifolius essential oil at $(0.9 \mathrm{ml} / \mathrm{L})$ in the second season. However the lowest FWR was obtained from the control treatment (21.46 and 21.83) in the two seasons, respectively .

Table (2). Average of final water uptake (g) and fresh weight/ dry weight ratio (FWR) of calla -lily cut flowers as affected by $8 \mathrm{HQS}$, Schinus terebinthifolius essential oil and citric acid in the seasons of 2014 and 2015.

\begin{tabular}{|c|c|c|c|c|}
\hline \multirow[t]{2}{*}{ Treatment } & \multicolumn{2}{|c|}{$\begin{array}{c}\text { Final water uptake } \\
(\mathrm{g})\end{array}$} & \multicolumn{2}{|c|}{$\begin{array}{c}\text { Flower fresh weight/flower dry } \\
\text { weight ratio (FWR) }\end{array}$} \\
\hline & 2014 & 2015 & 2014 & 2015 \\
\hline Control (distilled water) & $14.28^{\dagger}$ & $16.65^{\mathrm{e}}$ & $21.46^{d}$ & $21.83^{c}$ \\
\hline $8 \mathrm{HQS} 100 \mathrm{mg} / \mathrm{L}$ & $20.09^{c}$ & $23.21^{\mathrm{ab}}$ & $26.25^{\mathrm{bcd}}$ & $28.60^{\mathrm{ab}}$ \\
\hline $8 \mathrm{HQS} 150 \mathrm{mg} / \mathrm{L}$ & $17.89^{\text {de }}$ & $21.80^{\mathrm{bc}}$ & $24.77^{\mathrm{cd}}$ & $25.36^{\mathrm{abc}}$ \\
\hline $8 \mathrm{HQS} 200 \mathrm{mg} / \mathrm{L}$ & $19.13^{\mathrm{cd}}$ & $20.81^{c}$ & $27.15^{\mathrm{abcd}}$ & $27.74^{\mathrm{ab}}$ \\
\hline Essential oil $0.3 \mathrm{~m} / \mathrm{L}$ & $24.63^{\mathrm{ab}}$ & $22.19^{b c}$ & $29.67^{\mathrm{abc}}$ & $27.60^{\mathrm{ab}}$ \\
\hline Essential oil $0.6 \mathrm{~m} / \mathrm{L}$ & $22.76^{b}$ & $21.48^{c}$ & $30.21^{a b c}$ & $28.51^{\mathrm{ab}}$ \\
\hline Essential oil $0.9 \mathrm{~m} / \mathrm{L}$ & $24.79^{a}$ & $23.83^{a}$ & $32.19^{\mathrm{ab}}$ & $28.80^{\mathrm{a}}$ \\
\hline Citric acid $0.1 \mathrm{~g} . / \mathrm{L}$ & $18.07^{\mathrm{de}}$ & $17.64^{\mathrm{de}}$ & $26.28^{\mathrm{bcd}}$ & $24.15^{\mathrm{bc}}$ \\
\hline Citric acid 0.2 g./L & $16.37^{\mathrm{e}}$ & $18.26^{d}$ & $28.01^{\mathrm{abc}}$ & $27.42^{\mathrm{ab}}$ \\
\hline Citric acid $0.3 \mathrm{~g} . / \mathrm{L}$ & $19.44^{\mathrm{cd}}$ & $18.54^{d}$ & $33.17^{\mathrm{a}}$ & $29.58^{a}$ \\
\hline L.S.D.at 0.05 & 1.71 & 1.42 & 6.28 & 4.47 \\
\hline
\end{tabular}




\section{e-Relative fresh weight (RFW)}

Data presented in Table (3) showed that all $S$. terebinthifolius essential oil treatments gave a high significant increase in RFW along the experiment period as and the lowest significant RFW was obtained in the control treatment in both seasons.

Table (3). Average of relative fresh weight (RFW) of calla -lily cut flowers as affected by $8 \mathrm{HQS}$, Schinus terebinthifolius essential oil and citric acid in the seasons of 2014 and 2015.

\begin{tabular}{|c|c|c|c|c|c|c|}
\hline \multirow{3}{*}{ Treatment } & \multicolumn{6}{|c|}{ Relative fresh weight (RFW) } \\
\hline & \multicolumn{3}{|c|}{2014} & \multicolumn{3}{|c|}{2015} \\
\hline & $\begin{array}{l}11^{\text {th }} \\
\text { May }\end{array}$ & $\begin{array}{l}13^{\text {th }} \\
\text { May }\end{array}$ & $\begin{array}{l}15^{\text {th }} \\
\text { May }\end{array}$ & $\begin{array}{l}11^{\text {th }} \\
\text { May }\end{array}$ & $\begin{array}{l}13^{\text {th }} \\
\text { May }\end{array}$ & $\begin{array}{l}15^{\text {th }} \\
\text { May }\end{array}$ \\
\hline Control(distilled water) & $88.98^{\mathrm{e}}$ & 87.68 & $63.82^{d}$ & $88.69^{d}$ & $79.20^{\mathrm{e}}$ & $46.11^{\mathrm{e}}$ \\
\hline $8 \mathrm{HQS100} \mathrm{mg/L}$ & $91.63^{\text {cde }}$ & 90.56 & $72.57^{\mathrm{cb}}$ & $91.01^{\mathrm{bcd}}$ & $81.88^{\text {bced }}$ & $70.66^{\mathrm{bc}}$ \\
\hline $8 \mathrm{HQS150} \mathrm{mg} / \mathrm{L}$ & $90.84^{\mathrm{ed}}$ & 89.14 & $70.65^{\mathrm{c}}$ & $91.76^{\mathrm{bcd}}$ & $82.83^{\mathrm{abcd}}$ & $66.85^{d}$ \\
\hline $8 \mathrm{HQS200} \mathrm{mg/L}$ & $90.30^{\text {ed }}$ & 88.77 & $71.97^{\mathrm{cb}}$ & $90.17^{\mathrm{cd}}$ & $80.63^{\text {ed }}$ & $71.16^{\mathrm{cb}}$ \\
\hline Essential oil $0.3 \mathrm{~m} / \mathrm{L}$ & $94.06^{\mathrm{abc}}$ & 90.10 & $76.54^{\mathrm{ab}}$ & $93.46^{\mathrm{ab}}$ & $84.38^{\mathrm{ab}}$ & $75.75^{\mathrm{a}}$ \\
\hline Essential oil $0.6 \mathrm{~m} / \mathrm{L}$ & $95.17^{\mathrm{ab}}$ & 90.67 & $73.86^{\mathrm{abc}}$ & $95.29^{a}$ & $85.59^{a}$ & $75.69^{a}$ \\
\hline Essential oil $0.9 \mathrm{~m} / \mathrm{L}$ & $96.35^{\mathrm{a}}$ & 90.11 & $78.93^{\mathrm{a}}$ & $95.20^{\mathrm{a}}$ & $83.97^{\mathrm{abc}}$ & $74.97^{\mathrm{a}}$ \\
\hline Citric acid $0.1 \mathrm{~g} . / \mathrm{L}$ & $92.75^{\mathrm{bcd}}$ & 89.05 & $69.38^{\mathrm{cd}}$ & $91.34^{\mathrm{bcd}}$ & $80.72^{\text {de }}$ & $70.15^{\mathrm{cd}}$ \\
\hline Citric acid 0.2 g./L & $92.20^{\mathrm{cd}}$ & 89.86 & $73.08^{\mathrm{cb}}$ & $92.48^{\mathrm{abc}}$ & $81.02^{\text {bcde }}$ & $73.60^{\mathrm{ab}}$ \\
\hline Citric acid $0.3 \mathrm{~g} . / \mathrm{L}$ & $91.73^{\text {cde }}$ & 88.60 & $73.87^{\mathrm{abc}}$ & $92.37^{\mathrm{abc}}$ & $81.01^{\text {cde }}$ & $74.96^{\mathrm{a}}$ \\
\hline L.S.D.at 0.05 & 2.96 & N.S. & 5.7 & 3.27 & 3.18 & 3.31 \\
\hline
\end{tabular}

\section{f-Vase solution uptake rate (VSU)}

Data on Table (4) showed that the highest significant VSU was recorded after the treatment $0.9 \mathrm{ml} / \mathrm{L} \quad S$. terebinthifolius essential oil treatment (16.38) on the $11^{\text {th }}$ of May; this value was dropped sharply and recorded 5.34 on the $13^{\text {th }}$ of May and 7.53 on the $15^{\text {th }}$ of May. For 8 HQS treatments the VSU of the treatment $150 \mathrm{ppm}$ recorded 10.43 on the $11^{\text {th }}$ of May; this value dropped moderately and recorded 6.33 on the $13^{\text {th }}$ of May and 10.02 on the $15^{\text {th }}$ of May in 2014 season. The same trend was obtained on 2015 season. The treatment $0.9 \mathrm{~m} / \mathrm{L}$ S. terebinthifolius essential oil recorded (16.25) on the $11^{\text {th }}$ of May; this value decreased sharply and recorded 5.78 on the $13^{\text {th }}$ of May and 7.46 on the $15^{\text {th }}$ of May. For 8-HQS treatments the VSU of the treatment $150 \mathrm{ppm}$ was 10.23 on The $11^{\text {th }}$ of May this value dropped moderately and recorded 7.37 on the $13^{\text {th }}$ of May and 10.30 on the $15^{\text {th }}$ of May and the lowest VSU was obtained from the control treatment all over the two seasons . 
Table (4). Average of vase solution uptake rate (VSU) of calla -lily cut flowers as affected by $8 \mathrm{HQS}$, Schinus terebinthifolius essential oil and citric acid in the seasons of 2014 and 2015.

\begin{tabular}{|c|c|c|c|c|c|c|}
\hline \multirow{3}{*}{ Treatment } & \multicolumn{6}{|c|}{ Vase solution uptake rate ( VSU), \% } \\
\hline & \multicolumn{3}{|c|}{2014} & \multicolumn{3}{|c|}{2015} \\
\hline & $11^{\text {th }}$ May & $13^{\text {th }}$ May & $15^{\text {th }}$ May & $11^{\text {th }}$ May & $13^{\text {th }}$ May & $15^{\text {th }}$ May \\
\hline Control (distilled water) & $8.41^{\dagger}$ & $5.65^{\mathrm{bc}}$ & $5.99^{\mathrm{e}}$ & $11.72^{d}$ & $5.48^{\mathrm{d}}$ & $3.61^{\mathrm{g}}$ \\
\hline $8 \mathrm{HQS} 100 \mathrm{mg} / \mathrm{L}$ & $11.78^{\mathrm{cd}}$ & $6.69^{\mathrm{a}}$ & $9.41^{\mathrm{ab}}$ & $10.66^{\mathrm{d}}$ & $6.79^{\mathrm{bc}}$ & $8.42^{\mathrm{b}}$ \\
\hline $8 \mathrm{HQS} 150 \mathrm{mg} / \mathrm{L}$ & $10.43^{\text {de }}$ & $6.33^{\mathrm{ab}}$ & $10.02^{a}$ & $10.23^{d}$ & $7.37^{\mathrm{ab}}$ & $10.30^{a}$ \\
\hline $8 \mathrm{HQS} 200 \mathrm{mg} / \mathrm{L}$ & $9.89^{\text {ef }}$ & $6.70^{\mathrm{a}}$ & $8.88^{\mathrm{bc}}$ & $12.02^{\mathrm{cd}}$ & $8.07^{\mathrm{a}}$ & $7.42^{\mathrm{bcd}}$ \\
\hline Essential oil $0.3 \mathrm{~m} / \mathrm{L}$ & $14.53^{b}$ & $5.18^{c}$ & $8.08^{d}$ & $15.74^{\mathrm{ab}}$ & $7.22^{b}$ & $6.96^{\text {cde }}$ \\
\hline Essential oil $0.6 \mathrm{~m} / \mathrm{L}$ & $15.16^{\mathrm{ab}}$ & $5.42^{\mathrm{bc}}$ & $5.01^{e}$ & $14.09^{c}$ & $6.74^{c}$ & $6.57^{\mathrm{de}}$ \\
\hline Essential oil $0.9 \mathrm{~m} / \mathrm{L}$ & $16.38^{a}$ & $5.34^{\mathrm{bc}}$ & $7.53^{\text {de }}$ & $16.25^{\mathrm{a}}$ & $5.78^{\mathrm{C}}$ & $7.64^{\mathrm{bc}}$ \\
\hline Citric acid $0.1 \mathrm{~g} . / \mathrm{L}$ & $9.54^{\text {et }}$ & $5.64^{\mathrm{bc}}$ & $5.56^{\mathrm{e}}$ & $10.96^{d}$ & $5.54^{\mathrm{cd}}$ & $5.92^{\text {et }}$ \\
\hline Citric acid 0.2 g./L & $12.32^{c}$ & $4.73^{c}$ & $5.91^{e}$ & $9.44^{\mathrm{d}}$ & $4.79^{d}$ & $5.11^{\dagger}$ \\
\hline Citric acid $0.3 \mathrm{~g} . / \mathrm{L}$ & $11.10^{\text {cde }}$ & $5.21^{c}$ & $6.75^{\mathrm{e}}$ & $10.30^{d}$ & $4.40^{\mathrm{d}}$ & $5.68^{\text {et }}$ \\
\hline L.S.D.at 0.05 & 1.82 & 1.01 & 1.33 & 2.39 & 1.18 & 1.04 \\
\hline
\end{tabular}

Means of treatments in the column have the same letters, are not significantly different at $5 \%$ level.

\section{2-Chemical analysis}

Reducing sugar content

Data in Table (5) showed that for both seasons the lowest significant reducing sugar content was obtained after distilled water treatment as compared to the other treatments.

Table (5). Average reducing sugar content of calla -lily cut flowers as affected by $8 \mathrm{HQS}$, Schinus terebinthifolius essential oil and citric acid in the seasons of 2014 and 2015.

\begin{tabular}{|c|c|c|}
\hline \multirow{2}{*}{ Treatment } & \multicolumn{2}{|c|}{ Reducing sugar contents } \\
\hline & 2014 & 2015 \\
\hline Control (distilled water) & $2.30^{\mathrm{b}}$ & $2.12^{\mathrm{b}}$ \\
\hline 8HQS $100 \mathrm{ppm}$ & $3.21^{\mathrm{ab}}$ & $3.10^{a}$ \\
\hline 8HQS 150 ppm & $3.33^{\mathrm{a}}$ & $3.10^{\mathrm{a}}$ \\
\hline 8HQS 200 ppm & $3.33^{\mathrm{a}}$ & $3.27^{\mathrm{a}}$ \\
\hline Essential oil $0.3 \mathrm{~m} / \mathrm{L}$ & $2.99^{\mathrm{ab}}$ & $3.26^{\mathrm{a}}$ \\
\hline Essential oil $0.6 \mathrm{~m} / \mathrm{L}$ & $3.03^{\mathrm{ab}}$ & $3.37^{\mathrm{a}}$ \\
\hline Essential oil $0.9 \mathrm{~m} / \mathrm{L}$ & $3.03^{\mathrm{ab}}$ & $3.47^{\mathrm{a}}$ \\
\hline Citric acid $0.1 \mathrm{~g} . / \mathrm{L}$ & $2.68^{\mathrm{ab}}$ & $3.08^{\mathrm{a}}$ \\
\hline Citric acid $0.2 \mathrm{~g} . / \mathrm{L}$ & $3.19^{\mathrm{ab}}$ & $2.91^{\mathrm{a}}$ \\
\hline Citric acid $0.3 \mathrm{~g} . / \mathrm{L}$ & $3.33^{\mathrm{a}}$ & $3.13^{\mathrm{a}}$ \\
\hline L.S.D.at 0.05 & 0.91 & 0.66 \\
\hline
\end{tabular}

Means of treatments in the column have the same letters, are not significantly different at $5 \%$ level .

\section{DISCUSSION}

From the previous results it was noticed that all treatments led to a significant increase in calla - lily vase life .The positive effect of 8hydroxyquinoline sulphate (8-HQS) may act as an antimicrobial agent and hence, reduce stem plugging and preventing the accumulation of microorganism in xylem vessels (Larsen and Cromarty, 1967). Also it is clear from the results that $S$. terebinthifolius essential oil treatments prolonged the vase life of calla-lily flowers and these results could be due to the antibacterial and antifungal activities of the oil (Gundidza et al. 2009). Citric acid treatments 
led to caused increment in vase life this may be due to its act in reducing the $\mathrm{pH}$ of water and, consequently, the proliferation of bacteria, which block the xylem vessels in the cut region and interfere with the normal flux of water through the stem (Nowak \& Rudnicki, 1990). The lowest significant final water uptake, FWR values and highest significant LFFW was obtained from the distilled water treatment which may explain the lowest vase life of the control flowers. Also all the treatments led to a significant increase in reducing sugar content and this increment may increase the osmotic potential of the flowers, thus improving their ability to absorb nutrients and maintain their turgidity, which may explain the increase of flower longevity in different treatments in this study (Prathamesh and John 2013).

When flowers are detached from the plant, water loss continues through transpiration. The ideal flower preservative is that which allows water absorption in flower tissues or water absorption from the preservative solution maintains a better water balance and flower freshness and saves from early wilting resulting in enhancing vase-life. (Salunkhe et al., 1990). Our study cleared that for RFW values of the schinus oil treatments had high value along the experiment period which may illustrate the freshness and flower longevity of flowers after this treatments. Also, it has been noticed that the high value of VSU on the $11^{\text {th }}$ of May explains the freshness and flower longevity of calla flower from $S$. terebinthifolius oil treatments. Moreover, the moderate decrease of the VSU along the experiment period may clarify the increase of the flower longevity after 8-HQS treatments. Although the study demonstrated that the treatment of 8HQS at the rate of $200 \mathrm{ppm}$ and the treatments of $0.9 \mathrm{ml} / \mathrm{L}$ schinus oil had the same significant level in the vase life. The cut flowers resulted from the treatment $0.9 \mathrm{ml} / \mathrm{L} S$. terebinthifolius essential oil at the end of the experiment was more fresh than the cut flowers of $200 \mathrm{ppm}$ of 8-HQS this may be due to the lowest significant LFFW value in both seasons from $S$. terebinthifolius essential oil treatments and also due to the highest final water uptake from 0.9 $\mathrm{m} / \mathrm{L}$ S. terebinthifolius essential oil.

From the obtained results it could be recommended to use the S.terebinthifolius essential oil at the rate of $0.9 \mathrm{~m} / \mathrm{L}$ as natural environmentally alternative flower biocide as compared to8-HQS treatments or the citric acid treatments.

\section{REFERENCES}

Ahsan, M., S. Rehman, A. Younis, A. Riaz, U. Tariq and R. Waqas. (2012). Different strategies to create earliness and enhance quality of tuberose Polianthes tuberosa L. cv. Single. Asian J. Pharmaceutical and Biological Res., 2: 84-89.

Beata, J. and S. Anna (2011). Effect of growth regulators on the postharvest longevity of cut flowers and leaves of the calla lily Zantedeschia spreng. Acta Agrobotanica, 64 (4): 91-98

Bhattacharjee, S. K., V. Singh, and N.K. Saxena, (1993). Studies on Vegetative Growth, Flowering, Flower Quality and Vase Life of Roses. Singapore J. of Primary Industries, 21 (2): 67-71. 
Brian, E.C. and E.W. Richard, (1991) . Paclobutrazol, Gibberellic Acid, and Rhizome Size Affect Growth and Flowering of Zantedeschia. Hort. Science, 26(2):133-135.

Chapman, KD. and S. Austinbrown ( 2007). Methods for extending the freshness of cut flowers, ornamental trees, and plant cuttings. Http://www.freepatentsonline.com. Accessed on June 2010.

Courtier, J. and G. Clarke. (1997) . Indoor plants " The essential guide to choosing and caring for house plants " The Reader's Digest Association, Inc . Italy :187.

Damunupola, J.W. (2009). Xylem flow in cut Acacia holosericea stems. Ph.D. Thesis. University of Queensland, Queensland, Australia.

Dole, J. M., F. Harold and P. Wilkins. (1999). Floriculture Principles and Species. Prentice Hall Inc, Upper Saddle River, New Jersey: 613.

Gundidza, M., N.Gweru, M.L. Magwa, V. Mmbengwa, and A. Samie, (2009). The chemical composition and biological activities of essential oil from the fresh leaves of Schinus terebinthifolius from Zimbabwe. African Journal of Biotechnology, 8: 7164-7169.

He, S.G., D.C. Joyce, D.E. Irving and J.D. Faragher. ( 2006). Stem end blockage in cut Grevilla 'Crimson Yul-lo' inflorescences. Postharvest Biology and Technology. 41: 78-84.

Hegazi, M.A. and G. El-Kot. (2009). Influences of some essential oils on vase life of Gladiolus hybrid, I. Spikes. International Agro J. Veterinary Medicine Science, 3: 19-24.

Kader, A.A. (2003). A preservative on postharvest horticulture. J. Hort Science, 38: 1004-1008.

Larsen, F.E. and R.W. Cromarty. (1967). Micro-organism inhibition by 8hydroxyquinoline citrate as related to cut flower senescence. Proceeding American Society of Horticultural Science, 90: 546-549.

Loubaud, M. and W.G. Van Doorn. (2004). Wound-induced and bacterialinduced xylem blockage in roses, Astilbe and Viburnum. Postharvest Biol. Technol., 32: 281-288.

Mahmoud A.E.K (2013). Vegetable plants physiology. El-Maaref Publishers .Alexandria . P.302

Malik , C.P. and Singh (1980) . Plant enzymology and histoenymology . A Text manual, Kalyani publishers, New Delhi.

Manrique V., JP. Cuda, WA. Overholt and R. Diaz (2008). Temperature dependent development and potential distribution of Episimus utilis (Lepidoptera: Tortricidae), a candidate biological control agent of Brazilian peppertree (Sapindales: Anacardiaceae) in Florida. Environ. Entomol., 37(4): 862-70.

Molina-Salinas GM, A. Pérez-López, P. Becerril-Montes, R. Salazar-Aranda , S. Said-Fernández S and N.W. de torres (2006). Evaluation of the flora of northern Mexico for in vitro antimicrobial and antituberculosis activity. J. Ethnopharmacol, 109(3): 435-41.

Nowak, J. and R.M. Rudnicki, (1990). Postharvest handling and storage of cut flowers, florist greens and potted plants. Timber Press, Portland . 
Prathamesh, V. and P.C. John (2013) .Effect of biocides and sucrose on vase life and quality of cut gerbera Gerbera jamesonii cv. Maron Dementine. HortFlora Res.Spectrum, 2(3): 239-243.

Salem, M.Z.M., Ali, H.M., El-Shanhorey, N.A., Abdel-Megeed A. (2013). Evaluation of extracts and essential oil from Callistemon viminalis leaves: antibacterial and antioxidant activities, total phenolic and flavonoid contents. Asian Pacific Journal of Tropical Medicine, 6(10):785-791.

Salunkhe, D.K., Bhat, N.R. and B.B. Desai (1990). "Post-Harvest Biotechnology of Flowers and Ornamental Plants", Springer- Verlag, Berlin

Snedecor, G. W. and W. Cochran. (1989). Statistical Methods, Eighth Edition, lowa State University Press.

Solgi, M., T. Kafi, S. Taghavi and R. Naderi (2009). Essential oils and silver nanoparticles (SNP) as novel agents to extend vase-life of gerbera Gerbera jamesonii cv. 'Dune' flowers. Postharvest Biological and Technological, 53: 155-158.

Tarek A.M. , F.Y.E. Amira , A.M.K. Soad and F.M.E. Eman ( 2013). Impact of various pulsing and holding solutions on the quality and longevity of Nephrolepis exaltata (L.) Schott cut foliage under room temperature J. Hort. Sci. \& Ornamen. Plants, 5 (2): 89-99.

Tsegaw T, S. Tilahun and G. Humphries (2011). Influence of pulsing biocides and preservative solution treatment on the vase life of cut rose Rosa hybrid L. varieties. J. Appl. Sci. Technol., 2(2):1-18.

Van Doorn, W. G. (1997). Water relations of cut flowers. Hort. Rev., 18: 1-85.

Zamani S, M. Kazemi and M. Aran (2011). Postharvest life of cut rose flowers as affected by salicylic acid and glutamine. World Appl. Sci. J., 12(9):1621- 1624.

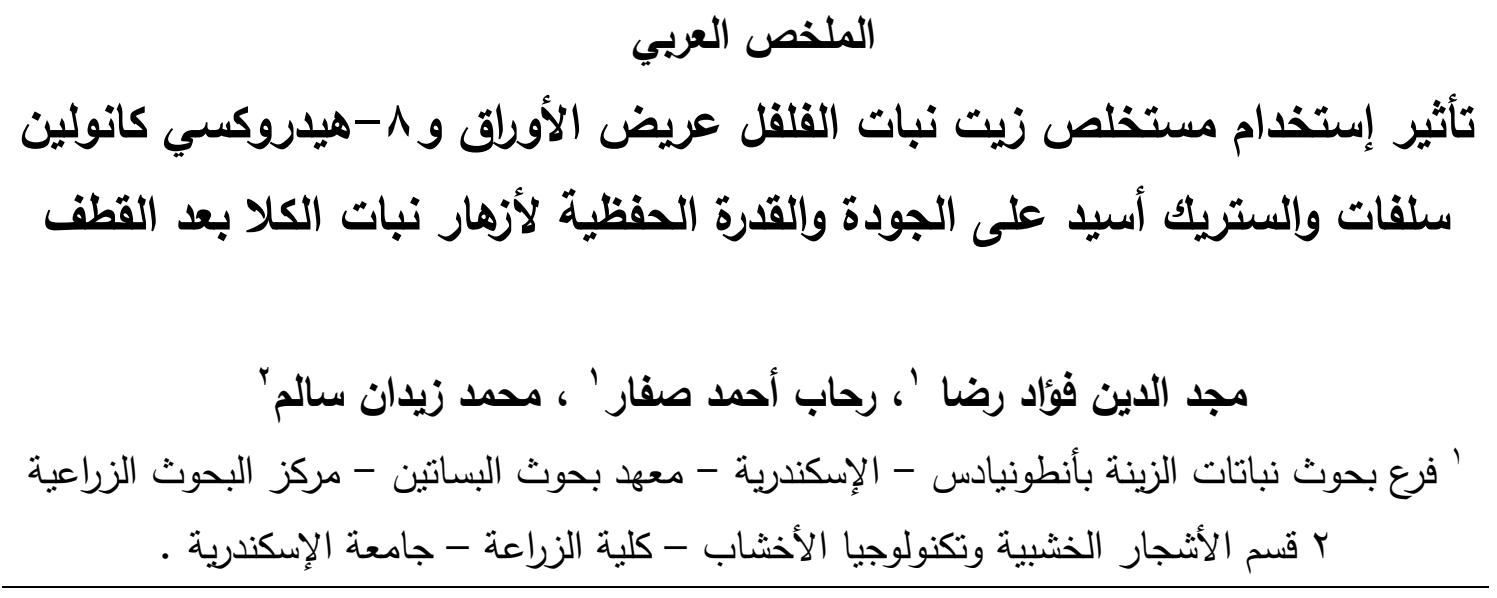

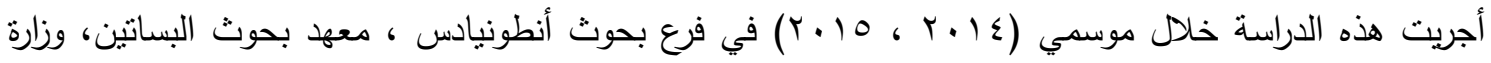

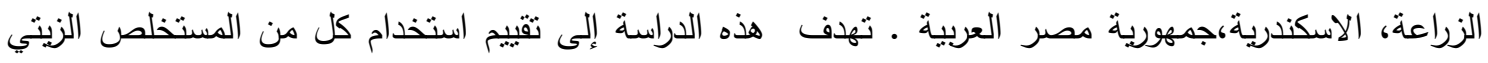

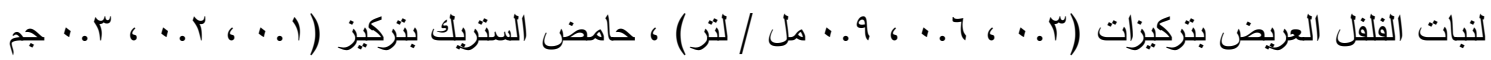

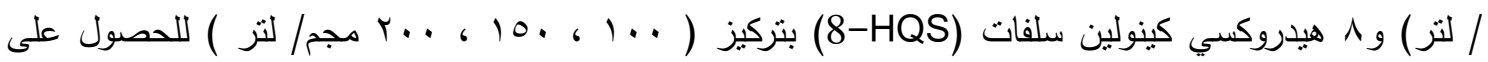


أفضل المعاملات لتحسين جودة أزهار الكلا و طول بقائها في الفازة ـ أظهرت النتائج أن جميع المعاملات

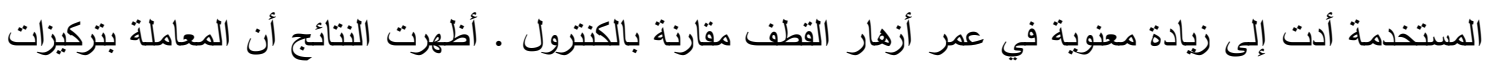
الزيت المختلفة أعطت أقل نسبة مئوية للفقد في الوزن الخضري في كلادئ الموسمين ـ بينما أعطت نتائج المعاملة بمستخلص الزيت بتركيز ( 9. . مل/ لتر ) أعلى معدل امتصاص للماء في كلا الموسمين مما أدى إلى بقاء الأزهار أكثر نضارة وكان محتوي السكريات المختزلة المتحصل عليه من جميع المعاملات أفضل من الكنترول ،

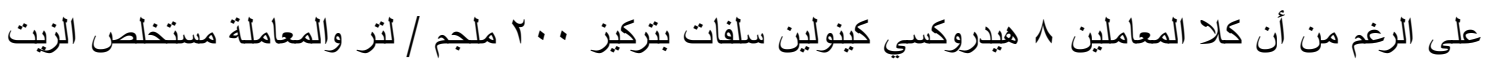

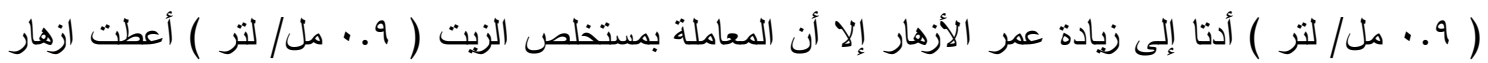
أكثر نضارة . الكلمات الدالة : عمر الأزهار- أزهار الكلا - 1 هيدروكسي كينولين سلفات- حامض الستريك - الزيت المستخلص من نبات الفلفل عريض الأوراق • 
